\title{
The role of military expenditure and arms imports in the Greek debt crisis
}

\section{Eftychia Nikolaidou}

Eftychia Nikolaidou is Associate Professor of Economics at the University of Cape Town, Cape Town, South Africa. She may be reached at efi.nikolaidou@uct.ac.za.

\section{Abstract}

Despite the vast amount of empirical work performed on the defense-growth relationship, the impact of military expenditure on public debt is a largely neglected topic. The recent Greek debt crisis brought to the forefront the role of military expenditure as well as the inefficiencies and the inability of the EU to deal with the European debt crisis. This article investigates the role of military expenditure (among other factors) in the evolution of the Greek debt over the period 1970-2011. Greece is a particularly interesting case in this regard, given its high military burden since 1974 and the recent debt crisis that led the country to sign a bail-out package presented by the European Union, the European Central Bank, and the International Monetary Fund, which involves extreme austerity measures and cuts in public spending. Employing the ARDL approach to cointegration, this article concludes that military expenditure and arms imports have had an adverse (i.e., increasing) effect on Greek public debt in the short-run, while investment has helped to reduce debt both in the short- and the long-run.

$\mathrm{T}$ he Greek debt crisis started in 2009, soon to be transmitted to the rest of Europe: Mediterranean EU countries-Italy, Spain, and Portugal (known, along with Greece, as the peripheral EU countries) - were most profoundly affected. Greece first signed a bail-out package presented by the EU, the ECB, and the IMF (the "Troika") in 2010. It involved the adoption of severe austerity measures (spending cuts and increases in taxation) as well as the implementation of structural reforms. Despite the severity of the measures, years later, Greece still found itself in a very difficult economic situation, with public debt at around 175 percent of GDP in 2014 and suffering from a deep, continuous recession. According to the World Bank, between 2008 to 2014, real GDP declined by 25.7 percent, from USD269 billion to USD200 billion, while unemployment increased from 9 to 27 percent. The austerity measures imposed on Greece by the $\mathrm{EU}$, the ECB, and the IMF also triggered debates among academics, journalists, and the general public regarding the role and sustainability both of the EU and the eurozone.

A topic often neglected in identifying the underlying reasons for high Greek public debt is its military expenditure. Greece stands out in comparison to other EU countries in terms of both high public debt and high military burden. The country's military burden has been well above the EU and NATO averages since 1974, the year that saw the collapse of Greece's military government and Turkey's invasion of Cyprus. ${ }^{1}$ The main justification for continuous high military expenditure has been the perceived threat from Turkey. Despite Greek efforts to develop a domestic defense industry since the mid-1970s, the industry remains underdeveloped and the country largely relies on arms imports. In 2009, at the beginning of the debt crisis, Greece was the world's fifth biggest arms importer (after India, Malaysia, Singapore, and China), with most of the imports coming from the United States, Germany, and France. Undoubtedly, the French and German arms industries gained a lot from Greece's excessive spending. In the five years up to 2010 , Greece purchased more of Germany's arms exports than any other country, and most of these purchases involved great scandals and corruption among Greek politicians and German companies. Since 2010, military expenditure cuts for Greece (and also for Italy and Spain) were among the largest in Western Europe. ${ }^{2}$

This article argues that, among other factors, military expenditure contributed to the build-up of Greece's public debt. It also criticizes the EU as, since 1981, when Greece became a member of the European Community, the country was indirectly compelled to import military equipment from EU countries in order to deal with the perceived Turkish threat. In addition, joining the EU made Greece more reliant on imports and the country cut home production since then. The two main objectives of the article are to assess the fundamental problems of the country, along with the role of the EU, and to provide some empirical evidence regarding the role of military expenditure in Greek public debt by employing the ARDL approach to cointegration over the period 1970-2011.

The next section briefly reviews the limited literature on the military expenditure - public debt nexus. An overview of the Greek economy follows, focusing on the evolution of Greek public debt and military expenditure as well as on the country's main security considerations. A further section presents the 
data, model, and findings. The last section concludes the article and provides some policy-related recommendations.

\section{Literature review}

Many studies investigate the economic effects of military expenditure or the economic effects of public debt but only a few look at the impact of military expenditure on public debt. Greece stands out in comparison to other EU countries in terms of both high debt and high military burden. Despite this, the role of military expenditure in understanding the indebtedness of the Greek state has received little attention.

Greece has been a big importer of military equipment since the mid-1970s. Imports of sophisticated weapons and other military equipment can be financed at the cost of investment and/or of human capital formation, or at the cost of increased foreign debt. Military expenditure is financed by taxation but when tax revenues are not enough, as in the Greek case, the country runs a budget deficit. Ordinarily, this can be covered by printing money-but not in this case as Greek monetary policy is in the hands of the ECB - or by using foreign exchange reserves, if available, or by borrowing domestically or internationally. But borrowing to finance arms imports has cumulative effects on debt through interest payments. ${ }^{3}$

Studies on military expenditure as a determinant of public debt in developing countries were first published in the early to mid-1980s. The findings suggest that military expenditure increases foreign debt and leads to reduced growth and also that military expenditure is import-intensive and increases public debt. Since then, additional studies that focus on developing countries have come to broadly similar conclusions. Exceptions notwithstanding, studies which focus on more advanced economies likewise have found an increasing effect of military expenditure on public debt growth. ${ }^{4}$

Although the literature on the determinants of public debt does not provide clear guidance regarding possible explanatory variables, typically, apart from military expenditure (or even better, arms imports, if data are available), most studies consider real GDP or real GDP per capita as a proxy for a country's capacity to borrow internationally: Higher output implies a higher debt ceiling as well as higher collateral for the borrower. If richer countries have greater capacity to repay debt, they nonetheless might borrow less, leading to a negative relation of GDP to debt. Yet, it is equally plausible that higher GDP encourages governments to spend more, for example on defense, in which case a positive effect on debt is expected. ${ }^{5}$

Greece: Economy and security

The pre-EU period

With a population of just below 11 million people, Greece is a
This article argues that military expenditure (among other factors) contributed to the build-up of Greece's public debt. It also criticizes the $\mathbf{E U}$ as, since 1981, when Greece became a member of the European Community, the country was indirectly compelled to import military equipment from $\mathbf{E U}$ countries in order to deal with the perceived Turkish threat.

small country. Located in the southern Balkans at an important geostrategic point between the East and the West, it was until the late 1950s an underdeveloped country characterized by low-productivity agriculture and a very weak industrial sector. This situation was partly attributable to Greece's civil war (1944-1949), which became an important element in the cold war as it was believed that the Soviet Union was supporting Greek communists. Meanwhile, the United States and the Greek army had become important forces in Greek politics, and Greece became tied to Western organizations such as the Organization for European Economic Co-operation (OEEC), the Council of Europe and, in 1952, NATO. During the post-1949 period, Greece's primary security concerns related to Warsaw Pact countries and to Turkey. By joining NATO, Greece secured its northern borders but not its eastern flank since the strategic interaction between Greece and Turkey has two contradictory facets: NATO allies, yet state to state adversaries. $^{6}$

After 1955, Greece's relations with the United States and the United Kingdom became troubled, partly because of resentment over U.S. influence in Greece but also because of the Cyprus problem. Cyprus was a British colony with a population that was 80 percent Greek and 20 percent Turkish. The Greek population wanted self-determination and enosis (union) with Greece. Naturally, the Athens government felt sympathy for Greek-Cypriots, thus provoking tensions with its NATO allies Britain and Turkey. In 1959, Cyprus gained independence from Britain, without enosis. Greek-Turkish tensions were renewed in 1964, and at that time UN forces were sent to the island. ${ }^{7}$

In the 1960s, Greece's economic structure experienced important qualitative changes. For the first time, in 1962, the contribution of the industrial sector to national output exceeded that of agriculture. During 1961-1970, Greece allocated an annual average of 4.3 percent of GDP to defense and saw an annual average GDP growth rate of 7.6 percent-well above the European average. The annual average rate of inflation was low at 3.1 percent. On 21 April 1967, a group of army colonels seized power in Athens. The military government that resulted remained in power for seven years (1967-1974), collapsing immediately after the Turkish invasion of Cyprus in 1974 which followed the Athens- instigated coup against the elected 
Table 1: Greek economic indicators

\begin{tabular}{|c|c|c|c|c|c|c|c|c|c|c|c|}
\hline & $\begin{array}{c}1971- \\
1980\end{array}$ & $\begin{array}{c}1981- \\
1990\end{array}$ & $\begin{array}{l}1991- \\
2000\end{array}$ & $\begin{array}{c}2001- \\
2010\end{array}$ & 2008 & 2009 & 2010 & 2011 & 2012 & 2013 & 2014 \\
\hline $\begin{array}{l}\text { GDP growth } \\
(\%)\end{array}$ & 4.70 & 0.71 & 2.48 & 1.80 & -0.34 & -4.30 & -5.48 & -9.13 & -7.30 & -3.20 & 0.65 \\
\hline $\begin{array}{l}\text { Investment } \\
\text { growth (\%) }\end{array}$ & 4.02 & -0.59 & 4.34 & 0.58 & -7.19 & -13.93 & -19.35 & -20.50 & -23.46 & -9.36 & -2.79 \\
\hline $\begin{array}{l}\text { Investment (\% } \\
\text { of GDP) }\end{array}$ & 30.21 & 24.57 & 22.26 & 23.07 & 23.81 & 20.79 & 17.56 & 15.27 & 12.62 & 12.02 & 11.61 \\
\hline Inflation (\%) & 14.50 & 19.0 & 9.40 & 3.30 & 4.15 & 1.21 & 4.71 & 3.33 & 1.51 & -0.92 & -1.31 \\
\hline $\begin{array}{l}\text { Public debt (\% } \\
\text { of GDP) }\end{array}$ & 20.70 & 49.8 & 97.40 & 110.6 & 112.9 & 129.7 & 148.3 & 170.9 & 156.5 & 174.9 & 177.2 \\
\hline $\begin{array}{l}\text { Milex }(\% \text { of } \\
\text { GDP) }\end{array}$ & 4.93 & 4.62 & 3.48 & 2.97 & 3.10 & 3.32 & 2.78 & 2.46 & 2.38 & 2.49 & 2.20 \\
\hline
\end{tabular}

Note: GDP and investment growth rates are calculated from constant 2005 USD. Sources: World Bank and SIPRI online data.

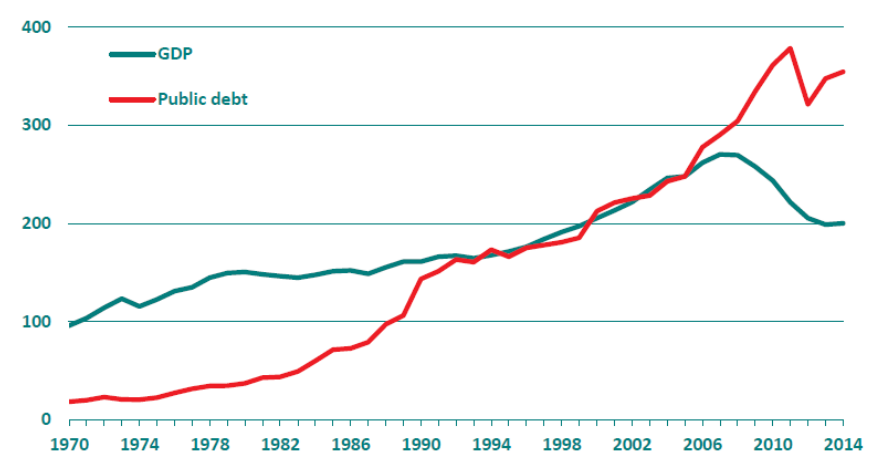

Figure 1: Greek real GDP and real public debt (in constant 2005 USD). Sources: See Table 1.

president of the Cypriot Republic. ${ }^{8}$

In these circumstances, the impressive growth rates of previous decades started to decline in the 1970s as structural weaknesses of the Greek economy became apparent. Yet even though the annual average GDP growth rate fell to 4.7 percent (in comparison to 7.6 percent in the previous decade), it was still well above the average of the then-European Community countries. Greece's military burden increased to just below 5 percent of GDP, and price inflation went up to 14.5 percent. Investment as a share of GDP was at around 30 percent (see Table 1). ${ }^{9}$ In the early 1970s, government-controlled defense industries were established, both because of weapons embargoes imposed during the seven year reign of the military government but also because Greece wanted independence in weapons procurement due to the increasing tensions with
Turkey. By the mid-1970s, the internal communist threat had disappeared yielding its place to the more traditional animosity with Turkey. In 1974, the Turkish invasion of Cyprus and the establishment of democracy in Greece marked a huge increase in military expenditure, and the threat of an outbreak of open confrontation with Turkey was considered high. ${ }^{10}$

Thus, 1974 was a very important year for Greek politics: It brought the collapse of the military dictatorship and coincided with the Turkish invasion of Cyprus. Since then, Greece has had Europe's and NATO's highest military burden, the underlying reason (or justification) being the perceived threat from Turkey. Furthermore, for many years after 1974 it was widely believed that there was an arms race between Greece and Turkey. This, however, is not backed up by empirical evidence. Most studies have rejected the existence of an arms race and have instead confirmed that the main determinant of Greek military expenditure is the Turkish threat. ${ }^{11}$

\section{The post-EU period}

In the 1980s, the Greek economy deteriorated. The average annual GDP growth rate was only 0.71 percent (the rest of Europe's was 2.3 percent), while inflation increased to an average of around 19 percent annually. Investment as a share of GDP declined, reaching an average of 24.5 percent of GDP for the decade. Despite the economic problems, military expenditure was kept at high levels: During the 1980s Greece allocated an annual average of 4.6 percent of GDP to defense. In 1981, Greece became a full member of the European Community (EC) and, since then, its debt started to increase 


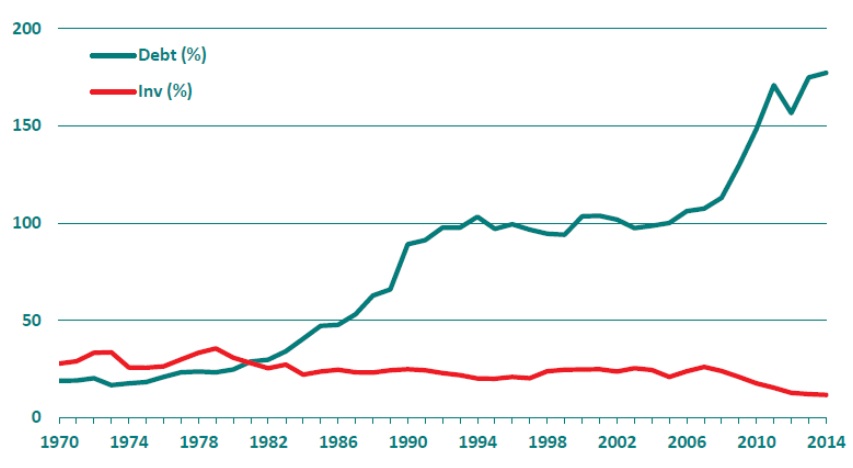

Figure 2: Greek public debt and investment as percent share of GDP. Sources: See Table 1.

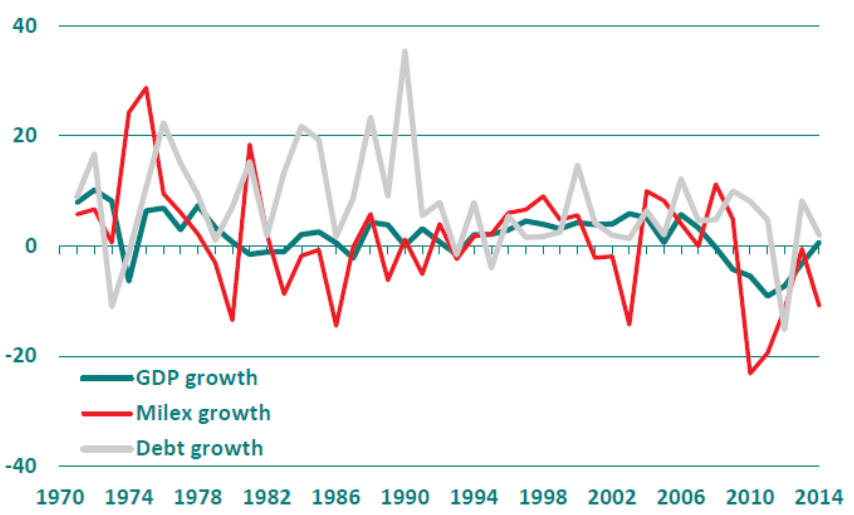

Figure 3: Annual Greek GDP, military expenditure (milex), and public debt growth (percent). Sources: See Table 1.

mainly due to the payment of high interest rates on previous debt as well as due to the country's inability to collect tax revenues, the expense involved in the state recapitalization of private banks, and excessive and unjustifiably high military expenditure. Prior to 1981, public debt was only 21 percent of GDP (see Table 1 and Figure 2) and Greece would borrow externally in order to finance investments. However, from 1981 onward, external borrowing was used to boost consumption and to increase the standard of living. By the end of the 1980s, public debt had reached 80 percent of GDP (Figure 2). Since the early 1980s, Greece had become a significant market for advanced weapons systems and this led to foreign trade deficits, shortages of foreign currency, and devaluation of the currency against the U.S. dollar. In 1985, Greece declared a defense doctrine that officially marked Turkey as the principal threat to its security. ${ }^{12}$

During the 1990s, deep concerns arose over the Balkan civil wars. Greeks were particularly upset by the creation of a state called Macedonia (as Macedonia is the name of the northern part of Greece). Also, there was some concern over the treatment of the Greek minority in Albania. Initially, these events seemed to signal additional security concerns for Greece but since none of these countries possessed large military establishments, Greek defense policy and military planning were not affected. Economic indicators improved slightly during the 1990s mainly because of Greece's effort to achieve the required criteria for joining the European Monetary Union. For this period (the 1990s), GDP growth increased to 2.5 percent while military burden fell to 3.5 percent because of the tight fiscal and macroeconomic policies put in place. Inflation was brought down to an annual average of 9.4 percent for the same period while investment as a share of GDP lay just above 22 percent. Despite these improvements, Greece's economy remained weak and performed well below the EU's average. Public debt as a share of GDP increased further, averaging just above 97 percent of GDP for the 1990s.

In 2001, when Greece joined the eurozone, the inflation rate was reduced further (averaging 3.3 percent for the decade) while over the period 2001-2008, low interest rates and increased borrowing led to increased investment (an average of 24 percent of GDP for these years) and high growth rates (3.5 percent, on average). Yet, low-cost borrowing in conjunction with low production encouraged excessive spending and private credit growth. Borrowing is not a bad thing if funds are used for productive investment and infrastructure. But this was not the case for Greece. After the collapse of the military government in 1974, all democratic parties in power secured votes by expanding the public sector. The huge, inefficient, and very well-paid public sector, the political connections required to find a job in the public sector (even without skills), the high pensions, and the generous retirement packages for public servants along with tax evasion, corruption, and bribes among politicians, civil servants, and tax officials (well described by the Greek words fakelaki and rousfeti) were (and probably still are) the fundamental problems of the Greek state. On top of this, dozens of closed professions (pharmacists, truck and bus owners, etc.) as well as labor union power have contributed to the lack of competitiveness in Greece. ${ }^{13}$

\section{The post-global financial crisis period}

In the wake of the burst of the global financial crisis, in 2008, European banks exposed to subprime-based mortgage-backed securities experienced losses, and the European Commission approved 4.5 trillion euros in aid for banks. For the euro periphery, the crisis triggered a major reassessment among investors of the sustainability of rapid credit growth and large external deficits. According to one author, it was the combined impact of domestic recessions, banking-sector distress, and the decline in risk appetite among international investors that led 
Table 2: A brief chronology of key events for Greece in the post-EU era
Jan. 1981 Greece joins the EC (later renamed EU).
2001 Greece joins the Eurozone. Was Greece
ready to join?
2007-2008 Global Financial Crisis.
18 Oct. 2009 Greek Prime Minister, George Papandreou, admits budget deficit is double the previous government's estimate and will reach 12.7 percent of GDP.

23 Apr. 2010 George Papandreou formally requests an international bail-out for Greece. The EU, $\mathrm{ECB}$, and IMF agree to participate. 1st bail-out package: $€ 110$ billion.

Feb. 2012 2nd bail-out package: $€ 130$ billion.

Mar. 2012 Private sector involvement- debt "haircut" (€ 107 billion).

5 Jul. 2015 Referendum: "Yes" or "No" to austerity measures and then the 3rd bail-out package of $€ 86$ billion.

to the European sovereign debt crisis. For Greece, this stressful situation was accompanied by the announcement, in October 2009, of a revised budget deficit of 12.7 percent of GDP (instead of 6 percent). Risk-spreads went sky-high, and no longer could Greece borrow on the international financial markets as rating agencies kept downgrading Greek bond issues. Six months later, Greece officially requested a bail-out. Table 2 summarizes the key events from 1981, when Greece joined the EU, up until July $2015 .^{14}$

The bail-out loans were accompanied by austerity measures imposed by the EU, the ECB, and the IMF. They included wage and pension cuts, fiscal reforms (raising taxes, cutting government spending, and tax system improvements to increase tax revenues and fight tax evasion), and various structural reforms such as opening up closed professions, reforming pension funds to make them viable in the future, lengthening the retirement eligibility age for women, making the labor market more flexible, privatizing public corporations and assets, and reducing state bureaucracy.

But was it really Greece that was bailed out at that point? I would argue that this was not the case. Instead, the aim of the initial bail-out was to offer a safe exit to private bondholders exposed to Greek bonds. One can easily confirm that by seeing

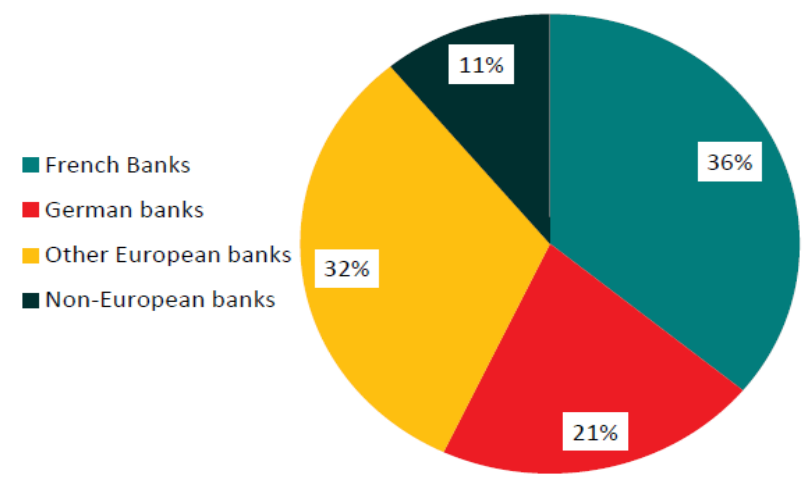

Figure 4(a): Holders of Greek public debt (end of 2009).
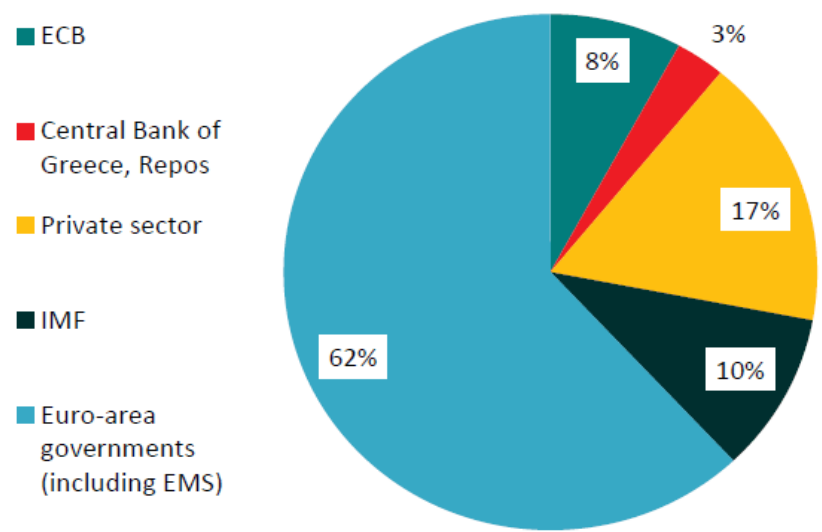

Figure 4(b): Holders of Greek public debt (end of 2014). Sources: Bloomberg; Greek Finance Ministry; European Commission.

where the monies went: Only 27 billion euros (11 percent of the total funding) were used for the Greek state's operating needs. The rest went to the country's banks and to foreign creditors, mostly French and German banks. Most of the bailout funds were used to bail out, directly or indirectly, the financial sector (both Greek and foreign) - not Greece. The overwhelming part of Greek government debt was shifted from the private to the public sector, with other eurozone governments now liable for around 65 percent of Greece's debt (and another 20 percent in the hands of the ECB and IMF). These facts can easily be observed by comparing holders of Greek debt before and after the bail-out (Figure 4). ${ }^{15}$

\section{The current situation}

Between 2008 and 2014, Greece experienced years of deep recession, with real GDP down by nearly 26 percent, the overall unemployment rate climbing to 27 percent, and youth unemployment reaching an astounding 60 percent. Pensioners, the unemployed, and the poor are suffering ( 30 percent living below the poverty line, 17 percent unable to meet their daily 
Table 3: ARDL results, 1970-2011

Panel (a): ARDL $(1,0,0,0)$ with military expenditure

Estimated long-run coefficients

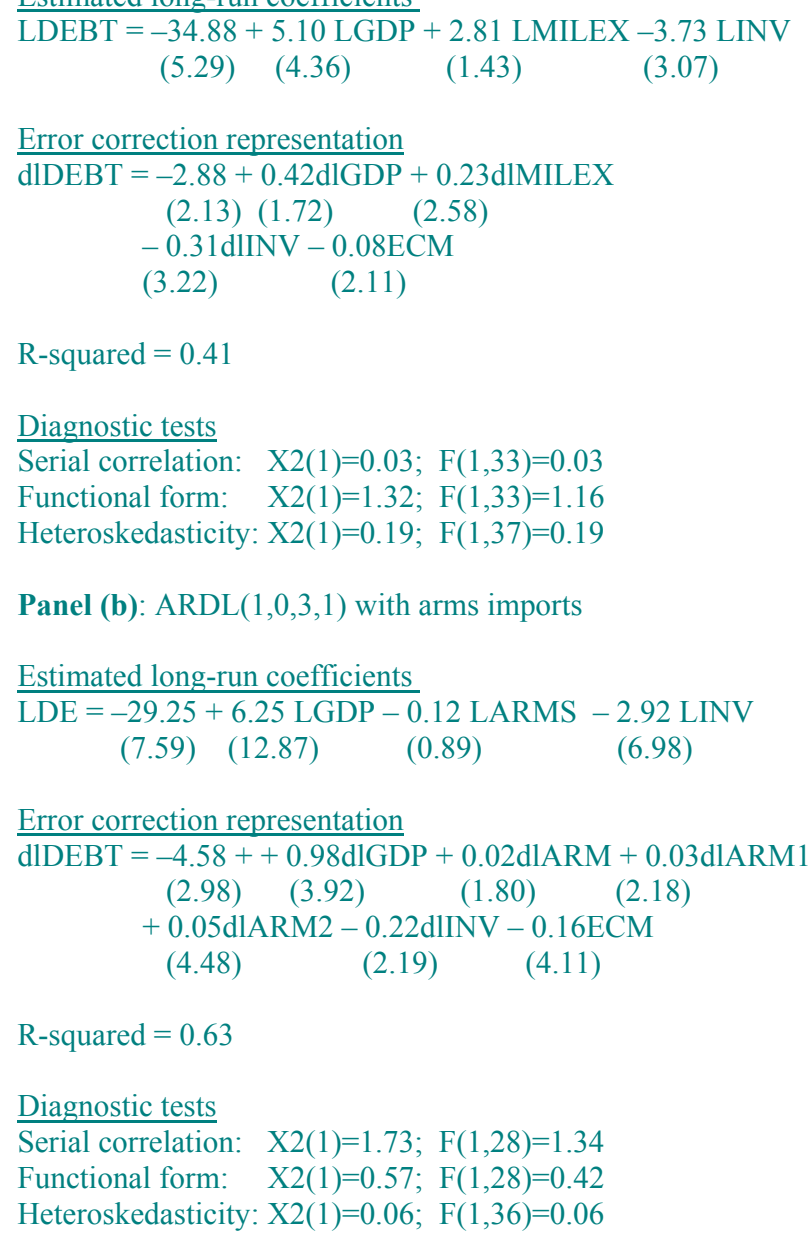

food needs, and 3.1 million people without health insurance). Surviving businesses are tired of uncertainty. People who still have a job face lower wages and higher taxation. Between 2010 and 2012, the suicide rate rose by 35 percent. Furthermore, Greece has suffered a severe brain drain: More than 120,000 professionals - including doctors, engineers, and scientists - have left Greece since the start of the crisis. These effects are, ironically, worse than any open warfare with Turkey might have been!

On top of this, the conflict with Turkey remains unsolved as disagreements over Cyprus, the extent of the continental self of the Aegean Sea, and the control of the airspace above it, persist. These security considerations, and the absence of EU support for an EU border country, compelled Greece to be a big defense spender and increase its public debt even as arms exporting countries, in particular France, Germany, and the
U.S., received substantial benefits from this constellation of forces for a good many years. ${ }^{16}$

Model, data, and findings

Following other authors, apart from income and military expenditure (or, alternatively, arms imports), investment is included in the model that is estimated by the ARDL approach to cointegration. The model is given by

\section{(1) $\mathrm{DEBT}=f\left(\mathrm{DEBT}_{-1}, \mathrm{GDP}, \mathrm{INV}, \mathrm{MILEX}\right.$ [or ARMS]),}

where DEBT is public debt; INV is gross fixed capital formation; MILEX is military expenditure; and ARMS is arms imports, all in real terms. DEBT $_{-1}$ is DEBT lagged by one time period. ${ }^{17}$

Data on debt, GDP, and investment come from the World Bank online database and data on military expenditure and arms imports from SIPRI, all for 1970-2011. All variables are in constant 2000 USD and transformed to their logarithmic forms. The model is first estimated using military expenditure, then using arms import data. The expectation is that either variable has a greater than zero effect on public debt, at least in the short-run. Regarding the GDP variable, the expected effect could either be negative (on the argument that higher GDP eases debt repayment) or positive (on the argument that higher GDP encourages governments to spend more on arms). Finally, investment is expected to lower public debt through the creation of jobs and the increase in international investors' and creditors' confidence (and hence result in lower interest rates).

Determining the order of integration of the variables is not necessary for the ARDL approach to cointegration as both $\mathrm{I}(0)$ and I(1) variables can be used. However, to confirm that the series are not $\mathrm{I}(2)$, all variables are tested for unit roots using the augmented Dickey Fuller, or ADF, test. The unit root tests suggest that all variables are integrated of order $1 .{ }^{18}$ The ARDL bounds approach is used to identify and examine the long-run relationship between DEBT and the explanatory variables.

The ARDL method has a number of advantages over other cointegration methods. A key advantage is that it can be applied regardless of whether the regressors are I(0) or I(1). While other cointegration techniques are sensitive to sample size, the ARDL approach is suitable even if the sample size is small. Moreover, it permits one the use of a number of lags to capture the data-generating process with a general-to-specific methodology. Also, the approach allows one to derive a dynamic error correction model (ECM) that integrates short-run dynamics with the long-run equilibrium without losing long-run information. Lastly, the ARDL approach generally provides unbiased estimates of the long-run model, 
even when some of the regressors are endogenous. ${ }^{19}$

Table 3, Panel (a) shows the long-run estimates and the error correction representation of the ARDL with the military expenditure variable. Panel (b) shows the results when the arms import variable is used. In both cases, the lag selection of the ARDL is based on the Schwarz Bayesian criterion. To sum up the empirical evidence in Table 3: The findings support the notion of a greater than zero effect of military expenditure (or arms imports) on Greek public debt only in the short-run. Higher income (GDP) has an increasing effect on debt as well, but in both the short- and the long-run. So, for Greece, the argument that higher income increases the capacity to borrow and results in more military expenditure applies. This accords with studies for developing and emerging markets but is in contrast to most other studies, which find a negative effect of income on public debt. Further, both models provide strong evidence that investment reduces public debt, both in the shortand the long-run. Taken together, these findings suggest that a reduction in public debt can come about with higher investment and lower military expenditure (or arms imports). ${ }^{20}$

\section{Conclusion}

This article has provided an overview of the Greek debt crisis, paying special attention to the role of military expenditure and arms imports as well as to the role of the EU. Lying at the crossroad between Orient and Occident, Greece encountered fundamental problems after the end of its civil war, and the turmoils following it, that its period of military dictatorship (until 1974) never managed to deal with. All Greek political parties after 1974 are to be blamed for creating an augmented, highly paid, and inefficient public sector in order to secure votes. Greek debt started growing in the early 1980s when it joined the EU (in 1981). Initially, the increase in public debt was due mainly to high interest payments on previous debt as well as to the inability of the state to collect taxes while, at the same time, a key concern was the expansion of the public sector. Yet one should not ignore the role of the EU itself, and clearly, some blame for Greece's problems lies with the EU.

Empirical evidence on the determinants of public debt for Greece supports the notion of a public debt-increasing effect of military expenditure (or arms imports) only in the short-run. Income appears to have such an effect both in the short-run and the long-run, a finding which supports the hypothesis that higher income increases the capacity to borrow (and lower income reduces it). This is not a surprising finding for Greece given its irresponsible governments over the last 40 years. On the other hand, the results clearly suggest that investment reduces public debt, both in the short- and long-run (when either the military expenditure or the arms imports variable is used).

These findings carry important policy implications as Greece struggles to reduce its public debt. Although military expenditure in general, and arms imports specifically, have been dramatically reduced in the post-crisis years, there has been no increase in investment. This is not surprising given international investors' lack of confidence in a country chaffing under a cruel austerity program and tight deadlines imposed by the EU, the ECB, and the IMF - not to mention the political instability following the election of a radical left wing-oriented government in 2015. On top of these concerns, the still-huge bureaucracy continues to be a key obstacle for entrepreneurs and investors.

Extending the current policies will only prolong the stagnation or even deepen the recession of the Greek economy. According to a report by Oxfam: "Extreme austerity that reduces deficits but not debts is destructive and does not create opportunities for the future." From a purely economic standpoint, there is little doubt that the Greek debt is unsustainable and debt relief should be considered. But debt is not a purely economic issue. It is mainly a political issue, and morality and culture play an important role as well. Since 1981, when Greece joined the EU, the strong EU members have been watching Greece's excessive military spending without any worries as they had huge benefits from arms exports. This is particularly the case for Germany and France which even after the start of the debt crisis refused to cancel arms deals with Greece. Had the EU guaranteed Greek borders with Turkey, Greece would not be spending excessive amounts on armaments, its military burden would be close to the EU average, and it could spend the amounts dedicated to defense to other, more growth-promoting sectors. The EU should finally accept the need to mitigate Greece's security concerns given the country's geostrategic position, serving, as it does, as an entry point to the EU. The recent refugee crisis makes clear that the EU now does have its own vested interests to assist Greece. $^{21}$

\section{Notes}

For helpful comments I thank Jurgen Brauer and the participants of the 19th Annual International Conference on Economics and Security, 25-27 June 2015, Grenoble, France.

\section{Nikolaidou (2008).}

2. Fifth biggest importer: SIPRI online arms transfer database. Corruption: Smith (2012). Greece's excessive spending: Haydon (2012).

\section{Brzoska (1994).}


4. Early studies: See Brzoska (1983); Looney and Frederiksen (1986). Since then: Recent studies include Wolde-Rufael (2009); Forslund, Lima, and Panizza (2011); Georgantopoulos and Tsanis (2011); Shahbaz, Shabbir, and Butt (2011); Zaman, et al. (2012); Anfofum, Andow, and Mohammed (2014); Muhauji and Ojah (2014). More advanced countries: Alami (2002) for the Arab region; Dunne, Perlo-Freeman, and Soydan (2004a) for 11 industrialized countries; Kollias, Manolas, and Paleologou (2004) for Greece; Gunluk-Senesen (2004) for Turkey; Smyth and Narayan (2009) for six Middle Eastern countries. Exception: Sezgin's (2004) study on Turkey found a negative effect of military expenditure on debt but this changed to a positive effect when arms imports were considered instead of military expenditure.

5. Capacity to borrow internationally: E.g., Looney (1989); Dunne, Perlo-Freeman, and Soydan (2004). Higher output implies: Smyth and Narayan (2009).

6. Contradictory facets: Sezer (1984).

7. Troubled relations: Veremis (1982).

8. Contribution of industry and agriculture: Kollias (1996).

9. Table 1, which runs through 2014, is in constant 2005 USD. Later on in this article, reference is made to a model estimated in constant 2000 USD, using data through 2011.

10. Traditional animosity: Avramides (1997).

11. Have rejected: Nikolaidou (2008). See Brauer (2002) for a comprehensive review of the literature of the time.

12. From 1981 onward: Kouretas and Vamis (2010).

13. Fundamental problems: See Michelis (2011) for a detailed discussion of the fundamental Greek problems. Fakelaki refers to a small envelope with money that Greeks visiting public service offices or public hospitals give to the attending public officer under the table to get "job done quickly," to receive preferential treatment, or to ask for favors. In return for a promise to vote for them, rousfeti refers to voters going to politicians' offices to ask for a favor (typically to give their sons/daughters/relatives/themselves a job in the public sector).

14. European Commission approved: European Commission (2012). One author: Lane (2012).

15. Where the monies went: See Mouzakis (2015). Overwhelming majority: Singh (2015).

16. Suicide rate: Rachiotis, et al. (2015). Brain drain: Lambrianidis and Vogiatzis (2013). Conflict with Turkey: For a comprehensive review of Greek-Turkish relations, see Constas (1991). From the Greek perspective, Turkey is characterized by imperialism and aims to change the status quo established by the treaties of Lausanne (1923), Montreux (1936), and Paris (1947). The 1974 Turkish invasion of Cyprus and the presently continuing occupation of 40 percent of the island by Turkish troops is viewed as proof of Turkey's ambitions and strategic aims.

17. Following other authors: Shahbaz, Shabbir, and Butt (2011) and Anfofum, Andow, and Mohammed (2014).
18. To save space, unit root results are not provided but are available upon request from the author.

19. The ARDL bounds approach: As advanced by Pesaran and Smith (1998), Pesaran and Shin (1999), and Pesaran, Shin, and Smith (2001). ARDL advantages: Engle and Granger (1987); Johansen (1991, 1995); Johansen and Juselius (1990). ARDL suitable even with small sample size: Odhiambo (2010). Dynamic ECM: Shrestha and Chowdhury (2005. Unbiased estimates: Harris and Sollis (2003).

20. Accords with other studies: For instance, Anfofum, Andow, and Mohammed (2014); Forslund, Lima, and Panizza (2011).

21. Oxfam: Oxfam (2011). From a purely economic standpoint: Nikiforos, Papadimitriou, and Zezza (2015).

References

Alami, R. 2004. "Military Debt: Perspectives from the Experience of Arab Countries." Defence and Peace Economics. Vol. 13, No. 1, pp.13-30. http://dx.doi.org/10.1080/10242690210964

Anfofum, A.A., H.A. Andow, and A.N. Mohammed. 2014. "Military Spending and External Debt Burden in Nigeria." International Journal of Education and Research. Vol. 2, No.7, pp. 611-626.

Avramides, C., 1997. "Alternative Models of Greek Defence Expenditures." Defence and Peace Economics. Vol. 8, No. 2, pp.145-187. http://dx.doi.org/10.1080/10430719708404874

Brauer, J. 2002. "Survey and Review of the Defense Economics Literature on Greece and Turkey: What Have We Learned?" Defence and Peace Economics. Vol. 13, No. 2, pp. 85-107. http://dx.doi.org/10.1080/10242690210969

Brzoska, M. 1983. "Research Communication: The Military Related External Debt of Third World Countries." Journal of Peace Research. Vol. 20, No. 3, pp. 271-277. http://dx.doi.org/10.1177/002234338302000308

Brzoska, M. 1994. "The Financing Factor in Military Trade." Defence and Peace Economics. Vol. 5, No. 1, pp. 67-80. http://dx.doi.org/10.1080/10430719408404780

Constas, D. 1991. The Greek-Turkish Conflict in the 1990s. London: Macmillan. http://dx.doi.org/10.1007/978-1-349-12014-7

Dunne, J.P., S. Perlo-Freeman, and A. Soydan. 2004. "Military Expenditure and Debt in Small Industrialised Economies: A Panel Analysis." Defence and Peace Economics. Vol. 15, No. 2, pp. 125-132. http://dx.doi.org/10.1080/1024269032000110504

Engle, R. and C. Granger. 1987. "Co-integration and Error Correction: Representation, Estimation and Testing." Econometrica. Vol. 55, No. 2, pp. 251-276. http://dx.doi.org/10.2307/1913236

European Commission. 2012. "Tackling the Financial Crisis-Banks.” http://ec.europa.eu/competition/recovery/ financial_sector.html [accessed 24 March 2016]. 
Forslund, K., L. Lima, and V. Panizza. 2011. "The Determinants of the Composition of Public Debt in Developing and Emerging Market Countries." Review of Development Finance. Vol. 1, pp. 207-222. http://dx.doi.org/10.1016/j.rdf.2011.09.004

Georgantopoulos, A.G. and A.D. Tsamis. 2011. "The Interrelationship between Military Expenditure and External Debt : Patterns of Causation in Northern African Countries." Journal of Economics and Behavioral Studies. Vol. 3, No. 4, pp. 264-273.

Gunluk-Senesen, G. 2004. "The role of Defence on External Indebtedness: An Assessment for Turkey." Defence and Peace Economics. Vol. 15, No. 2, pp. 145-156. http://dx.doi.org/10.1080/1024269032000110522

Harris, R. and R. Sollis. 2003. Applied Time Series Modeling and Forecasting. New York: Wiley.

Haydon, P. 2012. "The Untold Story-Arms Imports and the Greek Debt Crisis." The Guardian (London). 9 March 2012.

Johansen, S. 1991. "Estimation and Hypothesis Testing of Cointegration Vectors in Gaussian Vector Autoregressive Models." Econometrica. Vol. 59, No. 6, pp. 1551-1580. http://dx.doi.org/10.2307/2938278

Johansen, S. and K. Juselius. 1990. "Maximum Likelihood Estimation and Inference on Cointegration- with Applications to the Demand for Money." Oxford Bulletin of Economics and Statistics.Vol. 52, No. 2, pp. 169-210. http://dx.doi.org/10.1111/j.1468-0084.1990.mp52002003.x

Kollias, C. 1996. "The Greek-Turkish Conflict and Greek Military Expenditure, 1960-92." Journal of Peace Research. Vol. 33, No. 2, pp. 217-228. http://dx.doi.org/10.1177/0022343396033002007

Kollias, C., G. Manolas, and S.M. Paleologou. 2004. "Military Expenditure and Government Debt in Greece: Some Preliminary Empirical Findings." Defence and Peace Economics. Vol. 15, No. 2, pp. 189-197. http://dx.doi.org/10.1080/1024269032000110559

Kouretas, G.P. and P. Vlamis. 2010. "The Greek Debt Crisis: Origins and Implications." Panoeconomicus. Vol. 57, No. 4, pp. 391-404. http://dx.doi.org/10.2298/PAN1004391K

Lambrianidis, L. and N. Vogiatzis. 2013. "Highly Skilled Migration: What Differentiates the 'Brains' who are Drained from those who Return in the Case of Greece?" Population, Space and Place. Vol. 19, No. 5, pp. 472-486. http://dx.doi.org/10.1002/psp.1726

Lane, P. 2012. “The European Sovereign Debt Crisis.” Journal of Economic Perspectives. Vol. 26, No. 3, pp. 49-68. http://dx.doi.org/10.1257/jep.26.3.49

Looney, R. and P.C. Frederiksen. 1986. "Defence Expenditures, External Public Debt and Growth in Developing Countries." Journal of Peace Research. Vol. 23, No. 4, pp. 329-337. http://dx.doi.org/10.1177/002234338602300403

Looney, R. 1989. "Internal and External Factors in Affecting Third World Military Expenditures." Journal of Peace
Research. Vol. 23, No. 4, pp. 329-338. http://dx.doi.org/10.1177/002234338602300403

Michelis, L. 2011. "The Greek Debt Crisis: Suggested Solutions and Reforms." The Rimini Centre for Economic Analysis, PR 11-01. http://www.rcfea.org/RePEc/pdf/ pre01_11.pdf [accessed 30 March 2016].

Mouzakis, Y. 2015. "Where did all the Money Go?" Macropolis: Greece in Perspective. 5 January 2015. www.macropolis.gr/?i=portal.en.the-agora.2080 [accessed 2 April 2016].

Muhauji, S. and K. Ojah. 2014. "External Debt and Military Spending: The Case of Africa's Conflict Countries." MPRA Paper 56077. University Library of Munich. https://mpra.ub.uni-muenchen.de/56077/1/MPRA_paper 56077.pdf.

Nikiforos, M., D.B. Papadimitriou, and G. Zezza. 2015. "The Greek Public Debt Problem.” Levy Economics Institute at Bard College. http://www.levyinstitute.org/pubs/ pn_15_2.pdf [accessed 24 March 2016].

Nikolaidou, E. 2008. "The Demand for Military Expenditure: Evidence from the EU15 (1961-2005)." Defence and Peace Economics. Vol. 19, No. 4, pp. 273-292.

http://dx.doi.org/10.1080/10242690802166533

Odhiambo, N. M. 2010. "Finance-Investment-Growth Nexus in South Africa: An ARDL Bounds Testing Procedure." Economic Change and Restructuring. Vol. 43, No. 3, pp. 205-219.

http://dx.doi.org/10.1007/s10644-010-9085-5

Oxfam. 2011. "A Cautionary Tale: The True Cost of Austerity and Inequality in Europe." Briefing Paper,. May 2011. https:/www.oxfam.org/sites/www.oxfam.org/files/bp174 -cautionary-tale-austerity-inequality-europe-120913-en_1 .pdf [accessed 30 March 2016].

Pesaran, M.H. and R.P. Smith. 1998. "Structural Analysis of Cointegrating VARs." Journal of Economic Surveys. Vol. 12, No. 5, pp. 471-505. http://dx.doi.org/10.1111/1467-6419.00065

Pesaran, M.H. and Y. Shin. 1999. "An Autoregressive Distributed Lag Modelling Approach to Cointegration Analysis," in S. Strom, A. Holly, and P. Diamond, eds., Econometrics and Economic Theory in the 20th Century: The Ragner Frisch Centennial Symposium. Cambridge, UK: Cambridge University Press. http://dx.doi.org/10.1017/CCOL521633230.011

Pesaran, M.H., Y. Shin, and R.P. Smith. 2001. "Bounds Testing Approaches to the Analysis of Level Relationships." Journal of Applied Econometrics. Vol. 16, No. 3, pp. 289-326. http://dx.doi.org/10.1002/jae.616

Rachiotis, G., D. Stuckler, M. McKee, and C. Hatzichristodoulou. 2015. "What has Happened to Suicides During the Greek Economic Crisis? Findings from an Ecological Study of Suicides and their Determinants (2003-2012)." BMJ Open. Vol. 5, No. 3. Bmjopen.bmj.com/content/5/3/e007295.

http://dx.doi.org/10.1136/bmjopen-2014-007295 
Sezer, D.B. 1984. “Turkey's Security Policies," pp. 43-89 in J. Alford, ed. Greece and Turkey: Adversity in Alliance. Aldershot, UK: Gower House.

Sezgin, S. 2004 "An Empirical Note on External Debt and Defence Expenditures in Turkey." Defence and Peace Economics. Vol. 15, No. 2, pp. 199-203. http://dx.doi.org/10.1080/1024269032000110568

Shahbaz, M., M.S. Shabbir, and M.S. Butt. 2011. "Does Military Spending Explode External Debt in Pakistan?" Defence and Peace Economics. Vol. 24, No. 2., pp. 105-120.

http://dx.doi.org/10.1080/10242694.2012.723159

Shrestha, M.B. and K. Chowdhury. 2005. "ARDL Modelling Approach to Testing the Financial Liberalisation Hypothesis." Working Paper 05-15. Department of Economics. University of Wollongong. http://ro.uow.edu.au/cgi/viewcontent.cgi?article $=1122 \& \mathrm{c}$ ontext=commwkpapers [accessed 20 March 2016].

Singh, K. 2015. "Who Owns Greece's Debt?" Global Research. 4 July 2015. http://www.globalresearch.ca/whoowns-greeces-debt/5460265 [accessed 30 March 2016].

Smith, H. 2012. 'German 'Hypocrisy' over Greek Military Spending has Critics up in Arms." The Guardian (London). 19 April 2012. www.theguardian.com/world/2012/apr/19 Greece-military-spending-debt-crisis.

Smyth, R. and K. Narayan. 2009. "A Panel Data Analysis of the Military Expenditure-External Debt Nexus: Evidence from Six Middle Eastern Countries." Journal of Peace Research. Vol. 46, No. 2, pp. 235-250. http://dx.doi.org/10.1177/0022343308100717

Veremis, T. 1982. "Greek Security: Issues and Politics." Adelphi Papers. No. 179. London: International Institute for Strategic Studies.

Wolde-Rufael, Y. 2009. "The Defence Spending-External Debt Nexus in Ethiopia." Defence and Peace Economics. Vol. 20, No. 5, pp. 423-436. http://dx.doi.org/10.1080/03066150902868171

Zaman, K., I.A. Shah, M.M. Khan, and M. Ahmad. 2012. "Cointegration Analysis of the Economic Growth, Military Expenditure and External Debt: Evidence from Pakistan." Journal of Economics and Business Research. Vol. 1, No. 18, pp. 91-117. 